\title{
Gotakur: An Android-Based Game for Children to Learn Addition and Subtraction Arithmetic Operations
}

\author{
Ika Rahmawati ${ }^{1, *}$ Ika F. Mahmudha ${ }^{1}$ \\ ${ }^{1}$ Faculty of Education, Universitas Negeri Surabaya, Surabaya, Indonesia \\ ${ }^{*}$ Corresponding author. Email: rahmaika13@gmail.com
}

\begin{abstract}
The research found that the difficulties of learning mathematics in addition and subtraction material caused by errors in applying a formula, errors in understanding the problem, and errors in understanding the number place value, in order to solve the problems, researchers conduct Gotakur (Addition and Subtraction Algorithm) as learning media. Due to the Covid-19 pandemic, which caused teaching and learning activities to be carried out online, the media was developed based on Android for 2nd-grade elementary schools. This research aims to: (1) Describe the development process of Gotakur (Android-based) for 2nd grade in elementary school; (2) Describe the validity of Gotakur (Android-based) for 2nd grade in elementary schools. This research applies the ADDIE (Analysis, Design, Development, Implementation, and Evaluation) model. At the implementation stage, the Gotakur trial was carried out by 2nd-grade students of SDN Gilang I Sidoarjo who obtained a questionnaire percentage of $95 \%$. The result of the material validation test obtained a percentage of $89.2 \%$, and the media validation obtained a percentage of $90.3 \%$. So, the conclusion obtained that Gotakur (Android-based) as learning media is appropriate to be used for learning addition and subtraction in elementary schools.
\end{abstract}

Keywords: Gotakur, Addition and Subtraction, Arithmetic Operations, Android, Games.

\section{INTRODUCTION}

Significant changes that occur in a short time are called revolutions. This is related to the entry of the industrial revolution 4.0 in Indonesia, where the tendency to use computers and robots to replace human labour. Of course, this revolution also has the impact of changes in the field of education that it is possible for teachers to be replaced by technology, but teachers equipped with technology will not be replaced. An example of a widely used technology is smartphones. Today elementary school students are skilled at using smartphones. Individuals who are active, skilful, and very familiar with digital languages and technologies are generally digital natives [1]. On the other hand, this raises concern among parents because children choose smartphones instead of studying. However, avoiding children from using smartphones is not the right solution considering they are digital natives. Parents and teachers can use this opportunity to realize mobile learning. Mobile learning is a type of learning delivered and supported by mobile technology, including smartphones, personal computers, and so on [2]. So the development of mobile learning can be an alternative or solution so that smartphones positively impact users of school-age children. The development of mobile learning is expected so that students can learn anywhere and anytime with the help of digital platforms that are familiar with students' lives.

The development of Android-based media in smartphones is also one of the steps that support ecodesign. Mobile learning is gradually becoming widely recognized by the public due to the availability of mobile and wireless devices with relatively low costs and supporting infrastructure and technology getting better [3]. Many conventional media certainly produce residues in the production and post-use processes. If it is damaged or not reused, many teachers are confused about processing the former learning media. In addition, Android-based learning media are lifetime because they are stored digitally, and Android-based learning media have a greater possibility of experiencing renewal.

The year 2020 will be a challenging year for the world due to the emergence of a new virus pandemic. A pandemic is a disease that attacks people on a large scale and occurs in many places, and the virus that causes the pandemic is Coronavirus or Covid-19. According to Hatip [4], Covid-19 changed the world of education since faceto-face learning became distance learning due to the pandemic. In implementing distance learning, the learning 
transformation that can be pursued includes the transformation of technology and learning media, learning design, learning models, assessment process and learning outcomes. Digital transformation is widely believed as the best way to stop the spread of Covid-19. It allows students' rights to obtain an education without neglecting the health and safety of the students. Hatip stated that learning must still be carried out during the pandemic even though it must be done at home [4].

Learning media is a tool to convey stimuli in the form of material to stimulate thoughts, feelings, and visions that lead to the learning process [5]. According to Kustiawan, Astuti, \& Tirtaningsih [6], learning media is a communication tool to convey information in material from the teacher to students during teaching and learning activities so that students are interested in receiving learning. So, it can be concluded that learning media, other than containing a material or teaching material, can attract students' attention and concretize something abstract.

Based on the researcher's interview with one of the teachers at the elementary school at SDN Gilang I Sidoarjo, the teacher still uses the word "save and debt" to teach addition material, especially compound addition and subtraction material with saving techniques. The word "save and debt" is still used because the teacher still has not found a solution to represent the concept in a composite addition operation with the technique of storing in a concrete form. The operation of addition and subtraction has long been used as an example of debt or borrowing. The use of the language of accounts payable is less educational because it does not carry a positive message [7].

Another problem faced by students is numeracy literacy. Low numeracy literacy skills make it difficult for students to understand the problems raised in the questions, especially story problems. Moreover, low numeracy skills make it difficult for students to operate the correct calculations. One alternative that can be used to solve these problems is to use concrete media that relates addition arithmetic operations to place value material and to design questions in the form of story questions to practice students' reading skills and understanding of questions[8]. One theory that can be used for problem-solving is Polya's theory. According to Polya[9], there are four steps to help solve problems, namely: (1) understanding the problem, (2) designing plans and problem-solving strategies, (3) implementing the plans and strategies that have been designed, (4) reexamining the results obtained.

From some of the problems that have been described, the current study is aimed to develop innovations by optimizing the use of technological sophistication in the world of education, that is, an Android-based educational game. The choice of android-based educational game media is because it can support distance learning, is friendly with students as digital natives, and seeks to increase the positive impacts of smartphones on students. By learning through games, students are expected to avoid boredom when learning mathematics and thus, improve students' understanding of compound addition and subtraction material. The game will be developed using Polya's solving theory as the basis for preparation. The game timeline that will be developed requires students to analyze problems in story problems, then plan problemsolving in mathematical form, then plan implementation with the help of in-game media, and finally check in the form of rewards and discussions.

\section{METHODS}

The type of research in Gotakur development is Research and Design research. The product resulting from this research is a learning media software that helps explain addition and subtraction material for the secondgrader. The research model used in this study is the ADDIE development model (Analysis, Design, Development or Production, Implementation or Delivery and Evaluation). The ADDIE model helps to design problem-solving in the learning process by developing products for learning. The preparation of the ADDIE model is carried out programmatically with a systematic sequence of stages to solve problems in learning related to learning resources tailored to the needs and characteristics of students [10]. The ADDIE model has five stages of development, namely Analysis, Design, Development, Implementation and Evaluation. Evaluation of the ADDIE research model is carried out at every stage to produce a quality product.

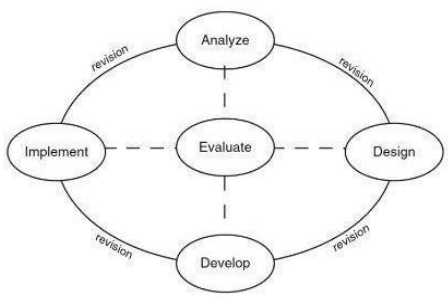

Figure 1 ADDIE model development stage 
In the analysis phase, the researcher conducted needs, student, and learning model analysis. At the design stage, the researchers designed media development, compiled materials, and developed research instruments. At the development stage, the researcher carried out the design at the design stage. Moreover, at the implementation stage, the researcher conducted a trial on 20 students at an elementary school Gilang $I$ in Sidoarjo. In this development research, two types of data will be obtained, namely quantitative and qualitative data. Qualitative data were obtained from experts who acted as validators in the form of suggestions and improvements in the columns provided on the validation sheet, and qualitative data were also obtained from users in the form of impressions and messages on the questionnaire sheet filled out by the teacher. While quantitative data is obtained from experts and users through scoring. Quantitative data were obtained from scoring results on material and media validation, as well as scoring on user questionnaires.

\section{RESULTS AND DISCUSSION}

\subsection{Results}

In the analysis stage, the researcher conducted needs analysis, student analysis and learning model analysis. The analysis activity begins with a needs analysis, the researcher examines the needs needed by teachers and students to be able to realize the ideal mathematics learning in elementary schools. The researcher conducted a non-formal interview with one of the teachers at SDN Gilang I Sidoarjo who stated that the learning media used to convey mathematics material was still very limited, especially when online learning was carried out. If learning is carried out face-to-face, the teacher can use concrete objects in the classroom as media, but when online learning is carried out, the teacher finds it difficult and requires media that can adapt the learning system.

Researchers also analyze the urgency of material that is fundamental or fundamental for students to learn. Based on the researcher's observations for simple addition and subtraction of numbers, the teacher uses media around students to help count like fingers, but the teacher finds it difficult to explain the material for addition and subtraction tiered to students concretely. In particular, the teacher found it difficult to find the right word other than the word "borrow" to describe ribbed addition with the saving technique, where the word has a negative connotation. The learning needs analysis and analysis of the urgency of this material become a reference for researchers to develop flexible mathematics learning media in the sense that it can be used for face-to-face and online learning systems to deliver addition and subtraction material to elementary school students.

In further analysis, the researcher also conducted a literature review related to students' interest in learning related to technology. In a journal written by Putra and Setyaningrum [11], they stated that learning mathematics using edutainment software is superior to that without edutainment software. With this conclusion, it is recommended that learning use edutainment media in learning mathematics. Teachers can use or develop applications or software that are following the material to be taught. It is undeniable that in the era of globalization, digitalization needs to be prepared so that students can face the ever-changing progress, including the advancement of ICT. The subsequent analysis is the learning model that is implemented. Due to the COVID19 pandemic, all schools in Indonesia are using the online model. Online learning is still considered the most effective alternative so far as the pandemic lasts to achieve learning objectives without compromising the health of students and educators [12].

The last stage in the analysis process is to carry out evaluation activities. The evaluation stage of the analysis carried out by the researcher is to determine the type of questions to be used, namely in the form of story questions related to events that students can encounter. Reference to the use of story questions based on Polya's problemsolving theory to help students hone problem-solving skills systematically.

After analyzing several aspects, the researcher continued the research towards the design stage. The researcher designs the media to be developed based on Android and material for determining mathematical problems relevant to public transportation. The androidbased media design was chosen based on the analysis results considering that currently, learning is done offline and online. So that android-based media can be flexible media to be used in both types of learning. Furthermore, the media design is detailed through flowcharts and storyboards. At the flowchart stage, the researcher designs the media flow. The media flow starts from the display of the main menu containing Gotakur. Then there is the mission menu which contains story questions about mathematical problems that can be relevant to the following means of transportation to carry out the mission 
directed to the Gotakur menu to help complete the calculations. If done correctly, players will get reward items that can be collected on the prize menu. The media display design is designed with wood nuances; the wood design can keep the children's focus on the numbers to comprehend the problem thoroughly. In addition, the wood nuance emphasizes simplicity so that it creates a calm impression. In the block game, letters and numbers keep the child's focus to recognize the alphabet or number blocks; it can be effective using the nuances of Montessori toys [13].

After completing the media and materials design stages, the design evaluation stage is carried out to optimize the materials and media for effective results for both researchers and users. In this evaluation, the researcher added instructions for use in videos accompanied by clear instructions to make it easier for users to understand the material and the course of the media.

The third stage is development; at this stage, the researcher realizes the results of the design stage according to what was designed based on the analysis stage to develop an android-based learning media. The tool used by researchers to develop Gotakur media based on Android is unity which is the primary processing, research music processing using DAW N-Track. The display processing begins by making a wooden background and then adding the buttons and items needed.

After the development stage is complete, the researcher validates, assisted by media experts and material experts. Based on material validation which produces an average percentage of $89.25 \%$, and media validation which produces an average percentage of $90.3 \%$, it can be concluded that the media and materials contained in Gotakur are declared valid. The last part of the development stage is evaluation. The evaluation is carried out by the researcher together with the media and material validators. The researchers make improvements or revisions by considering the suggestions and inputs given by the material and media validators.

After completing the development, the next stage in this research is implementation. The implementation stage is realized by testing the Android-based Gotakur media on second-grade students. Before the researcher distributed the Gotakur media at the implementation stage, the researchers and students held a Zoom meeting to provide a brief overview of this research and ensure that an Android-based smartphone was available to conduct media trials. The researcher also ensures and reviews the prerequisite material, namely place value, so there are no misconceptions when operating Gotakur media. The students looked enthusiastic by showing the activeness of answering when the researcher reviewed the place value material. All students attended the zoom meeting, but some students went in and out of the zoom meeting; however, overall, it went smoothly. After the zoom meeting was held, the researcher provided a link to download the Gotakur media. One student could not download Gotakur media due to limited facilities and infrastructure, so he did a trial using the smartphone of a classmate whose house was side by side. Researchers did not intervene during the trial, and instructions were provided in the application to make it easier for students to operate the media.

After the trial, the researcher distributed a questionnaire in the form of a google form related to the Gotakur media to find out user responses and an evaluation at the implementation stage. There are 15 questions with two answer choices, namely agree and disagree. The results of the questionnaire scores are calculated using the percentage of each aspect formula. The first aspect relates to the attractiveness of the media display, the second aspect relates to the colour used in the media, the third aspect relates to the clarity of the image on the media, the fourth aspect relates to the attractiveness of the image on the media, the fifth aspect relates to the ease of using the media, the sixth aspect relates to whether Gotakur media makes learning fun, the seventh aspect relates to the performance of buttons in the media, the eighth aspect relates to writing on the media, the ninth aspect relates to the suitability of the language used in the media, the tenth aspect relates to the clarity of commands in the media, the eleventh aspect relates to the explanation of instructions. Use, the twelfth aspect relates to the suitability of music in the media, the thirteenth aspect relates to whether the music used disturbs the user, the thirteenth aspect relates to the ease of learning to use the media, and the fifteenth aspect relates to student learning interest. 


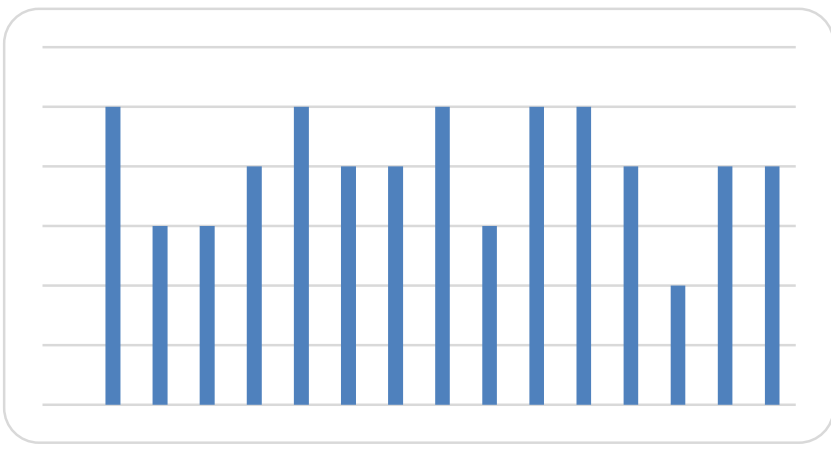

Diagram 1 Percentage of each aspect

Based on the results of the trial response to the use of Gotakur media, it can be seen that the average percentage of all aspects is $95 \%$. So, according to the media success criteria, it is stated that the Android-based Gotakur media is very feasible to be used by second-grade students to learn addition and subtraction material. With this conclusion, it is stated that the development of Androidbased Gotakur media at this stage is declared as the final product.

\subsection{Discussion}

Based on the implementation results in the form of media trials on 20 students, the Android-based Gotakur learning media was declared feasible to be used as a learning medium to help explain addition and subtraction material. Android-based Gotakur media also helps increase the enthusiasm of students when learning is carried out online, and this can be seen from the enthusiasm of students when researchers hold zoom meetings; this can also be proven from the results of student response questionnaires on aspects number 6 and 15 related with students' interest in learning while using Gotakur media which got a percentage of $95 \%$. During the zoom meeting, the students were enthusiastic because they could learn to use their respective mobile phones. This is in line with Puspitarini's opinion that one of the psychological functions of learning media is the function of attention, namely to attract students' attention to learning materials and activities [14]. Furthermore, based on research by Souza et al., learning mathematics using edutainment software is superior to without edutainment software. It is recommended for teachers to use edutainment media in learning mathematics. One form of edutainment is in the form of applications used for learning. For that, teachers must be able to develop their edutainment media [15].

The Android-based Gotakur learning media was developed by paying attention to every detail of the media to easily use it and make students interested in using the media. This is also evidenced by the questionnaire results on the ease of operation of the media in aspects 5 and 7 with percentage gains of $100 \%$ and $95 \%$, respectively. In addition to making the operation of the media as easy as possible, the researcher also provides instructions for use in the form of videos to help users who feel confused and instructions for use are equipped with explanations to instil the concept of addition and subtraction based on place value. This aims to instill the right concepts for students who are just learning composing addition and subtraction, against the background of Sidik's research which found the results that students' learning difficulties in doing addition and subtraction came from applied aspects, misunderstood the problem and misunderstood the place value in compound addition [16].

In addition to increasing the motivation of students, learning media also has the function of communication, meaning, equality of perception and individuality [17]. Learning media is used to facilitate communication between the sender of the message and the recipient of the message. The communication function is the main function of the media, especially for the elementary school level. Messages that are still in abstract form are conveyed in a more concrete form with the help of Gotakur media to help convey the existing message by reducing the verbalism that is often used, namely the word "borrowing" in stacked addition with the technique of storing. This is supported by data from the validation results in the input column and suggestions that Gotakur media helps teachers to explain addition and subtraction material.

The function of meaningfulness means that learning media adds information in the form of data and facts as the development of low-level and high-level cognitive aspects. Furthermore, the media can also be used to improve abilities in the aspects of attitudes and skills. On the mission menu, there are problems related to actual and factual problems, and there is also a narrative in the form of bonus missions to introduce exciting facts in the world of transportation while it also equipped with several pictures related to transportation in the form of buses, trains, ships and planes. Based on the results of the questionnaire regarding the images used, writing and language used in the media contained in aspects $3,4,8$ and 9 , each of which got a percentage of $90 \%, 95 \%, 100 \%$ and $95 \%$.

The function of the media as a perception equalization tool is expected to equalize perceptions so that each 
student has the same view of the material to be conveyed by the teacher. Learning media are all forms of learning resources that contain instructional learning materials [18]. The orders or instructions contained in the media are made as straightforward as possible to avoid ambiguity, as evidenced by the results of the aspect ten questionnaires related to the clarity of the commands used in learning media to get a percentage of $100 \%$. The function of individuality is intended to use learning media to help meet each individual (student) 's learning needs with different backgrounds. Gotakur media was developed based on Android, which aims to facilitate the distribution of media to all students during home learning activities so that each student can operate the media with the facilities and infrastructure available in their respective homes. It is also supported that there is only one student out of a total of 20 students. This can be overcome by borrowing the cell phone of one of his friends while studying together, which means that all 20 students can quickly access the media. In addition to this, the individuality function is also related to the level of media effectiveness perceived by students, as evidenced by the aspect 14 questionnaire relating to the ease of learning to use Gotakur media getting a percentage result of $95 \%$, meaning that Gotakur media can effectively help each student to learn. The information conveyed by the media is in the form of essential materials in learning so that students can construct their knowledge effectively and efficiently [19], [20].

\section{CONCLUSION}

Based on the research and discussion on the development of Android-based Gotakur media, it can be concluded that the development of Android-based Gotakur media for second-grade elementary schools uses the ADDIE development method (Analyze, Design, Development, Implementation, and Evaluation). At the analysis stage, needs analysis, student analysis and learning model analysis are carried out. At the design stage, the researchers designed media development, compiled materials, and developed research instruments. At the development stage, the researcher realized the design and validated the material with a percentage result of $89.2 \%$, which means very feasible and media validation results with a percentage of $90.3 \%$, which means very feasible - followed by the implementation stage to 20 seconds grade students of SDN Gilang I Sidoarjo with a media success rate of $95 \%$ based on user responses seen from the questionnaires distributed by researchers. The evaluation stage is carried out at each stage to produce a satisfactory final product. Based on the study results, it was stated that the Gotakur media was very feasible to be used in learning mathematics in addition and subtraction for second-grade elementary school.

After the completion of the development of Androidbased Gotakur media and based on the conclusions that have been written, there are several suggestions aimed at readers or further researchers as follows: 1) the development of Android-based Gotakur media is limited to addition and subtraction material up to 999 therefore further research can be developed into the subject broader discussion. 2) The results of this study can be followed up by examining the influence of Gotakur media on student learning outcomes. 3) the Gotakur application needs to be followed up by developing other arithmetic operations related to other real-life problems.

\section{REFERENCES}

[1] J. Y. Lee and D. Nuruddin Hidayat, "Digital technology for Indonesia's young people," Medien. Zeitschrift für Theor. und Prax. der Medien., vol. 35, no. 35, pp. 20-35, 2019, doi: 10.21240/mpaed/35/2019.10.17.x.

[2] B. Klimova, "Impact of Mobile Learning on Students," Educ. Sci., vol. 9, no. 2, p. 8, 2019.

[3] A. Jalil, M. Beer, and P. Crowther, "Pedagogical Requirements for Mobile Learning: A Review on MOBIlearn Task Model," J. Interact. Media Educ., vol. 2015, no. 1, pp. 1-17, 2015, doi: 10.5334/jime.ap.

[4] A. Hatip, "The Transformation Of Learning During Covid-19 Pandemic Towards The New Normal Era," Int. Webinar Educ., pp. 18-28, 2020.

[5] C. Nicolaou, M. Matsiola, and G. Kalliris, "Technology-enhanced learning and teaching methodologies through audiovisual media," Educ. Sci., vol. 9, no. 3, 2019, doi: 10.3390/educsci9030196.

[6] U. Kustiawan, W. Astuti, and M. T. Tirtaningsih, "Pengembangan Media Belajar Model-model Boneka dari Bahan Kain Flanel Berdasarkan Tema Kegiatan untuk Pembelajaran Anak Usia Dini," Edcomtech J. Kaji. Teknol. Pendidik., vol. 5, no. 2, pp. 137-144, 2020.

[7] F. Ramadania, N. I. Wulandari, and N. Nahlini, "Peranan komunikasi bahasa dalam pembelajaran matematika pada siswa kelas V SDN Keraton 3 Martapura," Math Didact. J. Pendidik. Mat., vol. 3, no. 1, pp. 23-32, 2018, doi: 10.33654/math.v3i1.52. 
[8] K. Ishaq, N. A. M. Zin, F. Rosdi, A. Abid, and U. Farooq, "Effectiveness of Literacy Numeracy Drive (LND): A Students' Perspective," 3rd Int. Conf. Innov. Comput. ICIC 2019, no. 978, 2019, doi: 10.1109/ICIC48496.2019.8966738.

[9] G. Polya, How to Solve It. Princeton University Press, 1973.

[10] R. M. Branch, Instructional design: The ADDIE approach. 2010.

[11] W. D. P. Putra and W. Setyaningrum, "The effect of edutainment toward students' interest in learning mathematics," J. Phys. Conf. Ser., vol. 1097, no. 1, 2018, doi: 10.1088/1742-6596/1097/1/012120.

[12] D. E. Pamungkas and Sukarman, "Transformasi Dunia Pendidikan di Sekolah Dasar dalam Masa Pandemi Covid-19," J. Rev. Pendidik. Dasar J. Kaji. Pendidik. dan Has. Penelit., vol. 6, no. 3, 2020.

[13] A. Lange, The Design of Childhood: How the Material World Shapes Independent Kids. New York: Bloomsbury Publishing, 2018.

[14] Y. D. Puspitarini and M. Hanif, "Using Learning Media to Increase Learning Motivation in Elementary School," Anatol. J. Educ., vol. 4, no. 2, pp. 53-60, 2019, doi: 10.29333/aje.2019.426a.
[15] B. Souza, M. Almeida, and R. Lopes, "A Decision Game for Informal Learning," Proceeding 13th Int. Conf. Comput. Support. Educ. (CSEDU 2021), vol. 1, no. Csedu, pp. 360-367, 2021, doi: $10.5220 / 0010492403600367$.

[16] G. S. Sidik, Di. Suryadi, and Turmudi, "Learning Obstacle of Addition Operation Whole Number in Elementary Schools," J. Phys. Conf. Ser., vol. 1842, no. 1, pp. 0-10, 2021, doi: 10.1088/17426596/1842/1/012070.

[17] W. Sanjaya, Media Komunikasi Pembelajaran. Jakarta: Prenada Media Group, 2012.

[18] E. R. Wati, Ragam Media Pembelajaran. Jakarta: Kata Pena, 2016.

[19] Muhammad Yaumi, Media \& Teknologi Pembelajaran. Jakarta: Prenada Media Group, 2018.

[20] L. de Sousa, B. Richter, and C. Nel, "The effect of multimedia use on the teaching and learning of Social Sciences at tertiary level: a case study," Yesterday and Today, no. 17, pp. 1-22, 2017, doi: 10.17159/2223-0386/2017/n17a1. 